\title{
A Scleractinian Coral (Plerogyra sinuosa) with 'Photosynthetic Organs'
}

\author{
H. Fricke ${ }^{1}$ and E. Vareschi ${ }^{2}$ \\ ${ }^{1}$ Max-Planck-Institut für Verhaltensphysiologie, D-8181 Seewiesen, Federal Republic of Germany \\ ${ }^{2}$ Zoologisches Institut der Universität München, Seidlstraße 25, D-8000 München 2, Federal Republic of Germany
}

\begin{abstract}
The scleractinian coral Plerogyra sinuosa DANA displays tentacles at night and globular bubbles during the day. Tentacles have few zooxanthellae $\left(760 \mathrm{~mm}^{-2}\right.$ of a transverse section) and a high nematocyst density $\left(1600 \mathrm{~mm}^{-2}\right)$; they are used for capturing planktonic prey. Bubbles have few nematocysts $\left(140 \mathrm{~mm}^{-2}\right)$ and a high density of zooxanthellae $\left(2300 \mathrm{~mm}^{-2}\right)$; they are used to foster the photosynthetic ability of the coral. At low light intensities the bubbles inflate up to $45 \mathrm{~mm}$ in diameter, while they contract at high light intensities. $P$. sinuosa preferentially occupies shaded areas in water of $<10 \mathrm{~m}$ depth. A new method for in situ oxygen measurements within the bubbles demonstrated a high photosynthetic activity $\left(\sim 70 \mathrm{mg} \mathrm{O} \mathrm{m}^{-2} \mathrm{~h}^{-1}\right)$ of the bubbles. These are interpreted as photosynthetic organs, enabling the coral to compete under a wide range of light conditions.
\end{abstract}

\section{INTRODUCTION}

While the association of scleractinian corals and endosymbiotic algae (zooxanthellae) facilitates rapid growth and development of shallow tropical coral reefs, some scleractinians have a wide bathymetric distribution (Wells, 1954; Goreau and Wells, 1967; Loya, 1972; Wethey and Porter, 1976; Dustan, 1979). Growth and survival in deeper waters with low ambient light conditions require special adaptations of zooxanthellae and corals: high photosynthetic efficiency (Wethey and Porter, 1976; Erez, 1978), high chlorophyll content and high density of algal cells (Kawaguti, 1937; Goreau, 1959, 1963; Kanwisher and Wainwright, 1967; Drew, 1972; Barnes and Taylor, 1973; Mergner and Svoboda, 1977; Dustan, 1979), reduction of polyps per unit area of coral (Dustan, 1979) and a shape that increases light-capturing abilities (Kawaguti, 1937; Goreau, 1959, 1963; Kanwisher and Wainwright, 1967; Barnes and Taylor, 1973; Dustan, 1979).

For the Indo-Pacific coral Plerogyra sinuosa Dana ('bubble coral') we report here another adaptation: light-dependent diel behaviour of a specialized morphological structure (see also Gladfelter, 1975). The

\footnotetext{
- Addressee for reprint requests
}

behavioural and morphological adaptations of $P$. sinuosa foster the photosynthetic ability of the coral and probably serve space partitioning; this could enhance the coral's competitive ability in shaded shallow areas as well as in deeper zones.

\section{METHODS}

Our study was carried out in June 1979 from the underwater house 'Neritica', stationed at Eilat (Israel) in the Red Sea, $70 \mathrm{~m}$ off shore, in front of the HeinzSteinitz Marine Laboratory. 'Neritica' was used as a base for SCUBA-diving and as an underwater laboratory. Dissolved oxygen in the open water was measured with a polarographic electrode (WTW Oxi 57; relative error $<2 \%$ ), temperature with a thermistor (WTW TE 56, relative error $<1 \%$ ) and photosynthetically active radiation (PAR, $400-700 \mu \mathrm{m}$ ) with a LiCor quantum sensor (Lambda Instr., relative error $<5 \%$ ). Chlorophyll was determined as acetone extract (Vollenweiler, 1969) of ground coral tissue. The density of nematocysts and zooxanthellae was counted from transverse sections (thickness $8 \mu \mathrm{m}$ ), stained with Lugol-solution and diluted $\mathrm{H}_{2} \mathrm{SO}_{4}$ (Gerlach, 1977). For the determination of diel variations in bubble size, colour slides of the same coral section were taken 
hourly. Later, the slides were projected and 5 randomly selected transects laid over the screen. Bubble and tentacle coverage along these transects were measured and expressed as percentages of transect length. In order to determine photosynthetic activity, oxygen concentration changes were measured inside the bubbles. Samples were obtained by carefully puncturing the bubbles with $5 \mathrm{ml}$ syringes ('Tuberculine' type, graduated in $0.05 \mathrm{ml}$ intervals) and fitted with No. 14 . (0.65 mm I.D.) needles. The bubbles kept tight around the needle, so that they collapsed when the water was drawn out, but a few minutes later they recovered their former size and shape; 5-20 bubbles were sampled for 1 syringe filling. Dissolved oxygen concentrations were measured with the Winkler method, modified from Carpenter's (1965) procedure.

The volume of the sample was reduced to exactly $5 \mathrm{ml}$. The Winkler-chemicals $(0.05 \mathrm{ml}$ manganous chloride, $0.05 \mathrm{ml}$ sodium hydroxide iodide and $0.1 \mathrm{ml}$ of the sulphuric acid reagent) were dispensed directly into the sampling syringe, using a $1 \mathrm{mI}$ 'Tuberculine'syringe, graduated in 0.01 intervals and fitted with a small rubber seal around the needle to prevent leakage; $<5$ min elapsed between sample extraction and fixation. The bottom of the sampling syringe and the piston together form a spherical cavity housing a $4 \mathrm{~mm}$ stainless steel ball. Shaking of the syringe liberates the ball and thus guarantees thorough mixing of the sample with the reagents. Titration was done in a magnetically stirred $25 \mathrm{ml}$ Erlmeyer flask with a $0.02 \mathrm{~N}$ sodium thiosulphate solution dispensed from a $2.5 \mathrm{ml}$ microburet (R. Gilmont; accuracy $10^{-4} \mathrm{ml}$ ). For error estimates artificial sea water was aerated by air, oxygen or nitrogen to obtain different oxygen concentrations. To test for accuracy, samples with oxygen concentrations of 0.6 to $28 \mathrm{mg} \mathrm{O} \mathrm{O}^{-1}$ were analyzed with the unimodified Winkler method according to Carpenter (1965) as control. Within the range of $1.5-21 \mathrm{mg}$ $\mathrm{O}_{2} 1^{-1}$ the results differed by $<5 \%$, in very high ( $>21 \mathrm{mg} \mathrm{O}_{2} \mathrm{l}^{-1}$ ) and very low $\left(<1.5 \mathrm{mg} \mathrm{O}_{2} \mathrm{l}^{-1}\right)$ oxygen concentrations by $<8.5 \%$. Standard deviations of 2 series of measurements were $\pm 2 \%$ and $\pm 2.3 \%$ of the mean.

\section{RESULTS AND DISCUSSION}

The brainlike coral Plerogyra sinuosa (maximum circumference $192 \mathrm{~cm}$ in the Nature Reserve, Eilat) is covered during the day with globular or elipsoid bubbles' measuring 10-20 mm in diameter (Fig. 1a), connected by tubes to the gastric cavity. The position of bubbles surrounded by tentacles at the polyp's oral disc suggest that the bubbles are modified tentacles. The bubbles contract at dusk and the surface of the
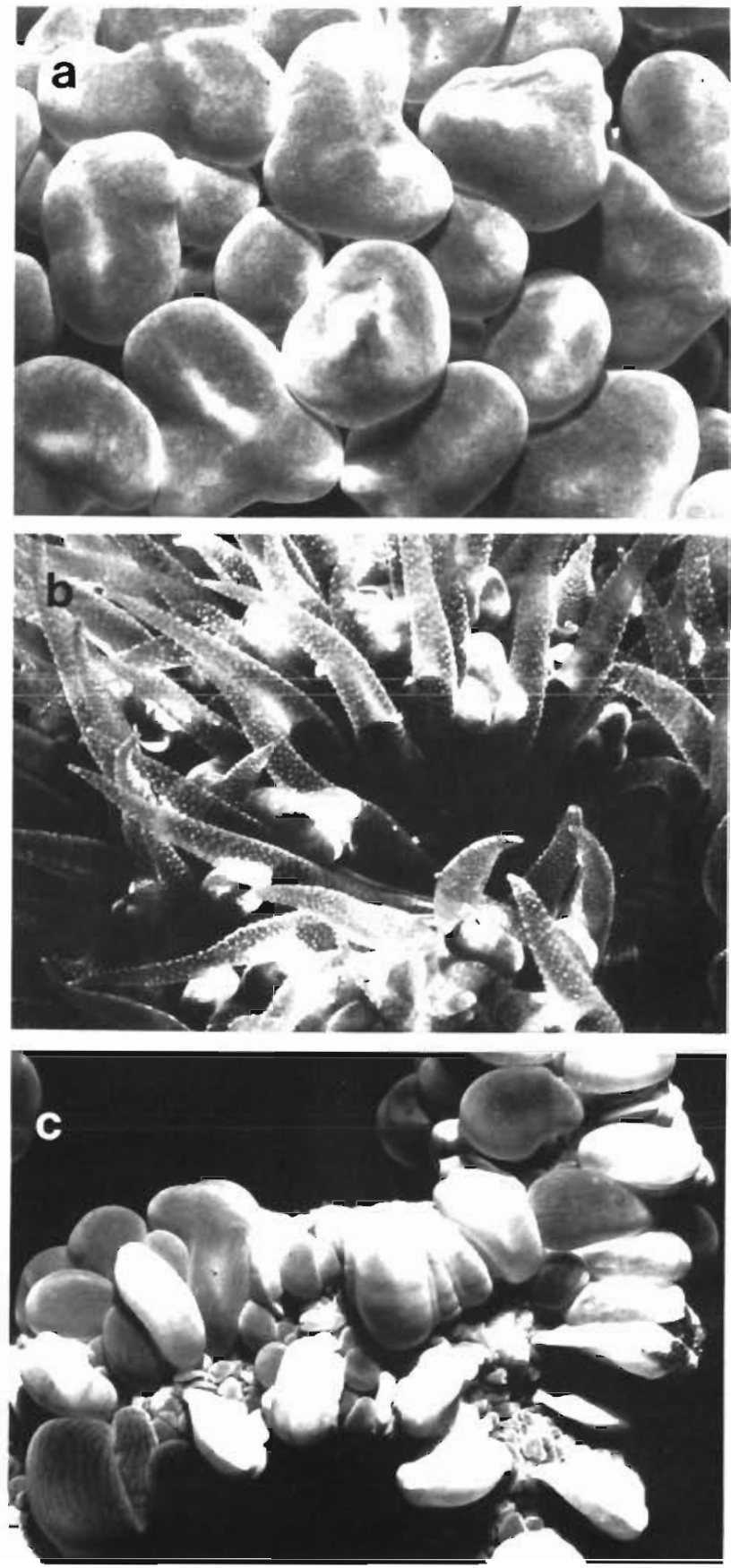

Fig. 1. Plerogyra sinuosa at different times of the day. (a) Bubbles 7.00 a.m.; (b) tentacles 8.00 p.m. (note contracted bubbles surrounded by tentacles); (c) partially contracted bubbles 2.00 p.m. water depth of coral: $12 \mathrm{~m}$. All photos taken from same distance

coral becomes thickly covered with tentacles, 3 at the base of each bubble (Fig. 1b). These tentacles capture planktonic prey; but in contrast to other reports (Scheer, 1971; Drew, 1972) we found no evidence that bubbles were also used for prey capture. Veron and Pichon (1980) suggest that bubbles may have a purely 
protective function. Our results indicate that bubbles have some function other than prey capture and protection.

Nematocyst density is much higher in tentacles $\left(1600 \pm 200[\mathrm{SE}] \mathrm{mm}^{-2}\right.$ of cross-sections) than in bubbles $\left(140 \pm 25 \mathrm{~mm}^{-2}\right)$, zooxanthellae density is higher in bubbles $\left(2300 \pm 160 \mathrm{~mm}^{-2}\right)$ than in tentacles $\left(760 \pm 50 \mathrm{~mm}^{-2}\right)$. In tentacles and coral tissue other than bubbles, zooxanthellae are aranged in several layers within an entoderm of $50-80 \mu \mathrm{m}$ (light hours, retracted tentacles) and they are covered by an ectoderm of 100-160 $\mu \mathrm{m}$. In bubbles, however, zooxanthellae are mostly aranged in 1 layer only within an entoderm of $10-25 \mu \mathrm{m}$ and covered by an ectoderm of 15-30 $\mu \mathrm{m}$ (light hours, expanded bubbles). Therefore, zooxanthellae in bubbles are in a better position to capture even small amounts of light than zooxanthellae in other coral tissue.

Fig. 2a illustrates the diurnal cycle of expansion and contraction of bubbles and tentacles in relation to light and temperature. Bubbles are only expanded during the day and tentacles are only expanded during the night. Endogenous control of this cyclic behaviour seems unlikely. When coral heads were transferred by day into dark chambers, the bubbles were slowly contracted and the tentacles expanded. Conversely, the illuminations of a coral head at night caused an immediate contraction of the tentacles and a slow expansion of bubbles. Because daily temperature changes (Fig. 2b) are minute $\left(26.1^{\circ} \mathrm{C} \pm 0.3 \mathrm{C}^{\circ}\right)$ and other exogenous environmental factors are unlikely to trigger the behaviour, bubble and tentacle expansion and contraction seem to be controlled by light conditions.

Bubbles also adjust in size to different light intensities. Fig. 3 shows that bubbles on shaded parts of the same coral head are significantly larger than on those exposed to light and that mean and maximum bubble size in both, light exposed and shaded areas, increase with water depth. The largest bubble of a coral in the Red Sea was $26 \mathrm{~mm}$ in diameter (26 $\mathrm{m}$ depth) and at the West Coast of Thailand $45 \mathrm{~mm}$ (21 $\mathrm{m}$ depth; Vareschi, unpubl.). Bubbles on heads in light-exposed shallow water are often contracted (Fig. 1c). This could reduce over-illumination of the zooxanthellae which may cause inhibition of photosynthesis as found in marine phytoplankton (Erez, 1978).

These results are a further argument for the ecotypic photoadaptability of Plerogyra sinuosa bubbles. Means adapted by other corals (see above) may be equally effective in coping with varying light conditions, but probably do not allow such differentiated

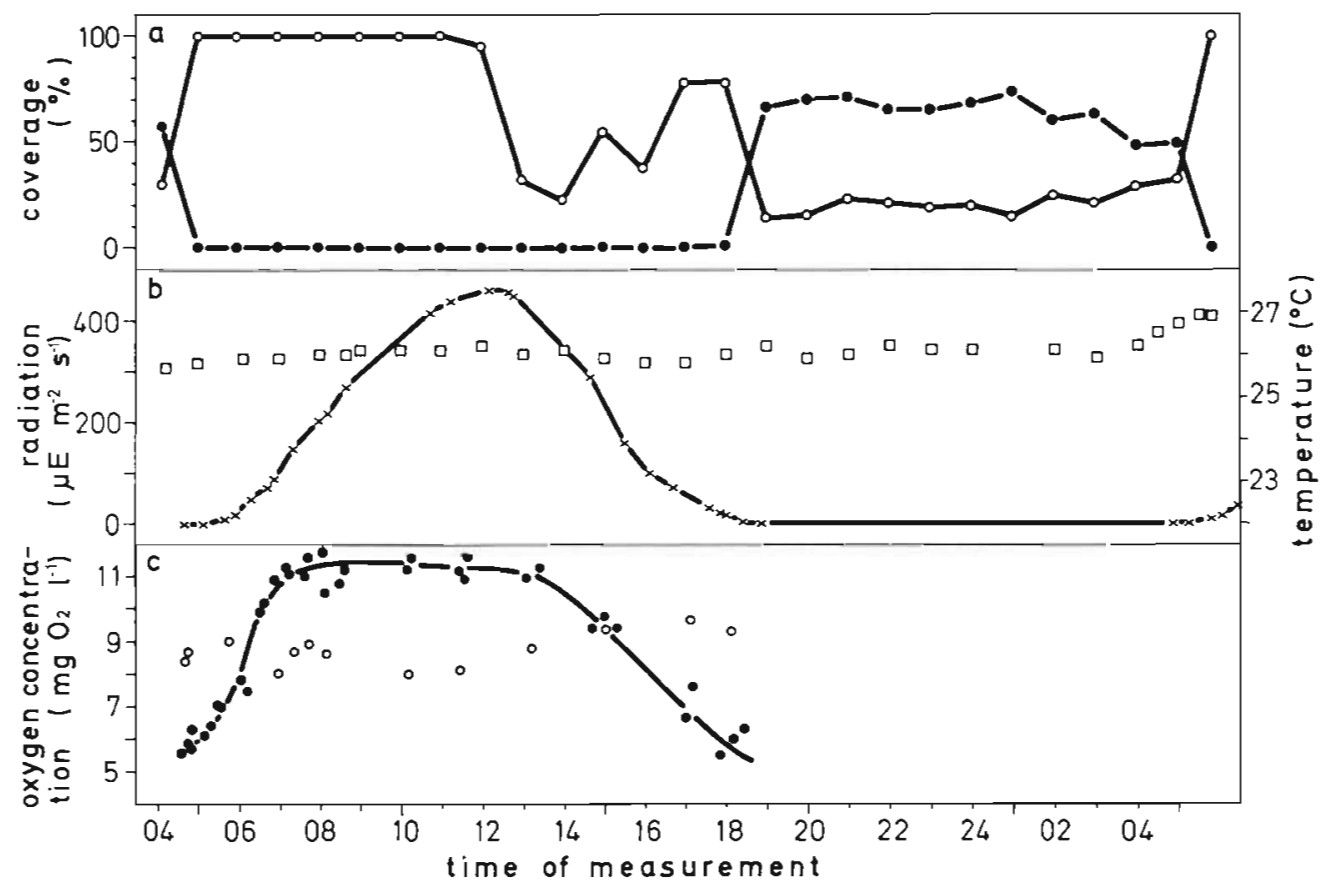

Fig. 2. Plerogyra sinuosa. Diel behaviour of expansion and contraction of bubbles and tentacles; oxygen concentration within expanded bubbles in relation to light and temperature (coral head in $12 \mathrm{~m}$ depth; 27-07-79). (a) Relative degrees of extension and contraction of bubbles and tentacles in relation to time of day; open circles: bubbles; filled circles: tentacles. (b) Light intensity and temperature at study site in relation to time of day; crosses: light intensity; squares: temperature. (c) Oxygen concentrations within bubbles and in ambient water in relation to time of day; open circles: oxygen concentration in ambient water; filled circles: oxygen concentration in bubbles 
responses, varying not only locally but within shorttime intervals.

The photosynthetic activity of the bubbles was tested by measuring the oxygen concentration within them. Fig. $2 c$ shows the diurnal changes in oxygen concentration. The drastic increase after sunrise indicates substantial oxygen production in the bubbles. Further increase in light intensity has no apparent effect on the oxygen concentration, probably because production rates are at their limits, and/or increasing oxygen diffusion into the open water. During late afternoon, respiration exceeds phytosynthesis and oxygen concentration decreases with waning light intensity. Similar features have been reported for other corals (e.g. Franzisket, 1969; Mergner and Svoboda, 1977; McCloskey et al., 1978). Different rates of photosynthetic activity also occur on sunny and shady parts of the same coral head. Measurements on a coral in $8 \mathrm{~m}$ depth at 4.10 p.m. gave an oxygen concentration of $6.5 \pm 0.6 \mathrm{mg} \mathrm{O}_{2} \mathrm{l}^{-1}$ (SE) for shaded areas and $9.1 \pm 0.9 \mathrm{mg} \mathrm{O} \mathrm{O}^{-1}$ for sun-exposed parts; in $12 \mathrm{~m}$ depth at 4.50 p.m. the corresponding values were $6.6 \pm 0.6$ and $9.0 \pm 0.9 \mathrm{mg} \mathrm{O} \mathrm{O}^{-1}$. Maximal oxygen generation within the bubbles was $7 \mathrm{mg} \mathrm{O} \mathrm{O}_{2}^{-1} \mathrm{~h}^{-1}$. These bubbles had a mean volume of $0.9 \mathrm{ml}$ and a mean projected area of $1.1 \mathrm{~cm}^{2}$. Therefore we estimate that the oxygen production of a Plerogyra sinuosa head could reach approximately $60 \mathrm{mg} \mathrm{O} \mathrm{O}_{2} \mathrm{~m}^{-2} \mathrm{~h}^{-1}$. Photosynthetic activity of the bubbles is linked with high pigment concentration. Extractions of chlorophyll a from a coral head in $12 \mathrm{~m}$ depth revealed a significantly higher content in bubbles than in tentacles (bubbles: $40.0 \pm 4.3 \mathrm{mg} \mathrm{Chl} \mathrm{a} \mathrm{g}{ }^{-1}$ dry weight, $\mathrm{n}=5$; tentacles: $16.7 \pm 6.1 \mathrm{mg} \mathrm{Chl} \mathrm{a} \mathrm{g}^{-1}$ dry weight, $\mathrm{n}=4$; $\mathrm{p}<0.01$, t-test; bubbles and tentacles were cut off in situ with small clippers).

The reported features of Plerogyra sinuosa bubbles (no prey capturing activity, low nematocyst density, high zooxanthellae density and high chlorophyll a content, substantial oxygen production and size adaptability in response to varying illumination) all support our hypothesis that the bubbles are specialized, inflatable organs of the coral which foster the zooxanthellae's photosynthesis. Hence we feel justified to call the bubbles 'photosynthetic organs' of the coral. Lightdependent activity patterns have also been reported for some scleractinian corals (Lasker, 1979) and anemones (Pearse, 1974).

Recent reports on Caribean sea anemones describe light-dependent behaviour of pseudotentacles and auxiliary structures of the column; these contain dense populations of zooxanthellae and they are considered to be light-capturing structures (Gladfelter, 1975; Sebens and DeRiemer, 1977). These features are similar to our findings in Plerogyra sinuosa. Faulkner and Chesher (1979) also interpreted $P$. sinuosa bubbles as means to enlarge the light-exposed surface.

Obviously coral geometry has evolved in response to
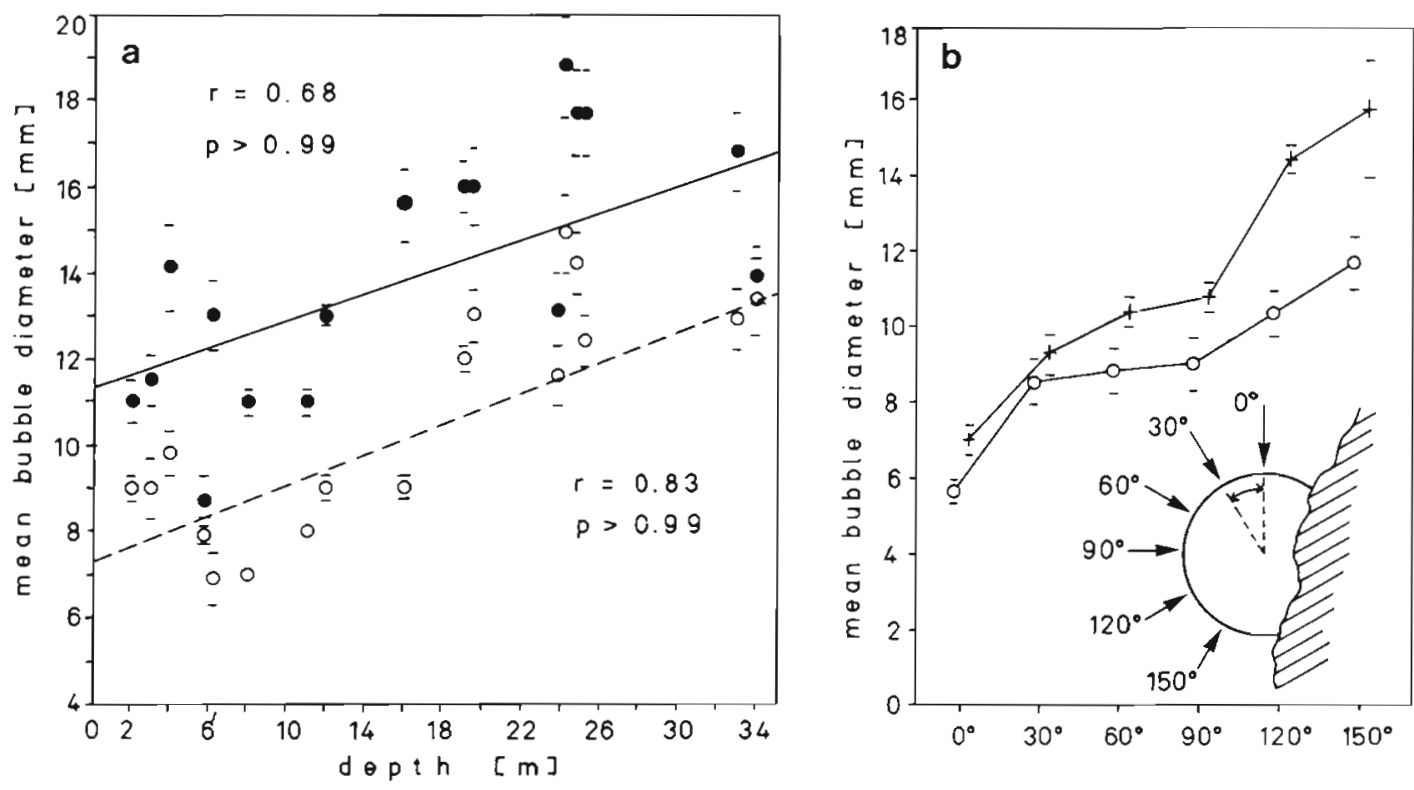

Fig. 3. Plerogyra sinuosa. Alteration of bubble size in relation to light intensity. (a) Mean diameter of bubbles in relation to depth in light-exposed parts (open circles: Lower regression line) and in shaded parts (filled circles: top regression line) of same coral head with standard errors (horizontal bars). All measurements taken between $11.00 \mathrm{a}$.m. and 12.30 p.m. on same day. (b) Mean diameter of bubbles measured from photographs taken at different angels of $0^{\circ}$ to $150^{\circ}$ to the vertical axis of 2 coral heads at depths of $2 \mathrm{~m}$ (crosses) and $4 \mathrm{~m}$ (circles); horizontal bars: standard errors. Bubble diameter increases from light-exposed to shaded parts of same coral head 
light and plankton capture. Different growth shapes at different depth are invariable, not flexible modifications of the coral. The morphological specialization in Plerogyra sinuosa, however, is a flexible and reversible adaptation enabling the coral to compete at a wide range of light intensities, down to the poor and scattered light conditions of overhung reef parts and crevices.

Plerogyra sinuosa is described as a very rare coral species in the Indo-Pacific Ocean, occurring in such diverse habitats as reef crest regions or even soft lagoon bottoms down to $35 \mathrm{~m}$ depth (Scheer, 1971; Pichon, 1972) preferring caves or crevices, where it grows on vertical faces or overhangs (Veron and Pichon, 1980). For Eilat, an optimum depth range of $20-40 \mathrm{~m}$ is reported (Loya and Slobodkin, 1971). However, coral counts in the Nature Reserve of Eilat along transects parallel to the coast down to $45 \mathrm{~m}$ indicate a main distribution of $P$. sinuosa along the reef edges between 3-6 m, where crevices and shaded overhung areas were preferentially occupied (Table 1). Recent

Table 1. Plerogyra sinuosa. Distribution in the Nature Reserve of Eilat, Israel, Gulf of Akaba. Transects of approx. $1200 \mathrm{~m}$ length were laid parallel to coastline. Shaded: corals in crevices or overhung areas; Light-exposed: corals in full sunlight

\begin{tabular}{|lrrrc|}
\hline Reef zonation & $\begin{array}{c}\text { Depth } \\
\text { (m) }\end{array}$ & $\begin{array}{l}\text { Number } \\
\text { of corals }\end{array}$ & Shaded $\begin{array}{c}\text { Light- } \\
\text { exposed }\end{array}$ \\
\hline Lagoon & $0-3$ & 4 & 4 & 0 \\
Reef edge & $1-6$ & 59 & 54 & 5 \\
Sandy area with & $3-12$ & 10 & 8 & 2 \\
Coral knolls & $16-22$ & 11 & 8 & 3 \\
Deep-water reef & & & & \\
\hline
\end{tabular}

counts near several small islands about $10 \mathrm{~km}$ off Phuket (West coast of Thailand) indicate a main distribution of $P$. sinuosa between 8 and $10 \mathrm{~m}$. Most coral heads deeper than $8 \mathrm{~m}$ were sun exposed, while coral heads between 0 and $6 \mathrm{~m}$ depth preferred shaded areas (Vareschi, unpubl.). H. Changsong (pers. comm.) found $P$. sinuosa to be among the commonest coral species near several islands about $50 \mathrm{~km}$ off Phuket at $15-20 \mathrm{~m}$ depth. These distributions indicate that $P$. sinuosa is best adapted to poor light intensities. The bubbles with their light-dependent behaviour should contribute significantly to this adaptation.

Acknowledgements. We wish to thank Y. Cohen, Director of Heinz-Steinitz Marine Laboratory in Eilat and U. Boonprakop. Director of Phuket Marine Biological Center for their warm hospitality, and J. Erez for many stimulating discussions; and all our students who so greatly helped us during the 'Neritica' operations.

\section{LITERATURE CITED}

Barnes, D. J., Taylor, D. L. (1973). In situ studies of calcification and photosynthetic carbon fixation in the coral Montastrea annularis. Helgoländer wiss. Meeresunters. 24: $284-291$

Carpenter, J. H. (1965). The Chesapeake Bay Institute Technique for the Winkler Dissolved Oxygen Method. Limnol. Oceanogr. 10: 141-143

McCloskey, L. R., Wethey, D. S., Porter, J W. (1978). Measurement and interpretation of photosynthesis and respiration in reef corals. In: Stoddart, D. R., Johannes, R. E. (eds.) Coral reefs: research methods. Monographs on oceanographic methodology 5, UNESCO, Paris, pp. 379-369

Drew, E. A. (1972). The biology and physiology of algaeinvertebrate symbiosis. II. The density of symbiotic algae cells in a number of hermatypic hard corals and alcyonarians from various depths. J. exp. mar. Biol. Ecol. 9: 71-75

Dustan, P. (1979). Distribution of zooxanthellae and photosynthetic chloroplast pigments of the reef-building coral Montastrea annularis Ellis and Solander in relation to depth on a West Indian coral reef. Bull. mar. Sci. 29: 79-95

Erez, J. (1978). Vital effect on stable-isotope composition seen in foraminifera and coral skeletons. Nature, Lond. 273: 199-202

Faulkner, D., Chesher, R. (1979). Living corals, Clarkson Potter, New York

Franzisket, L. (1969). The ratio of photosynthesis to respiration of reef building corals during a 24 hour period. Forma et functio $1: 153-158$

Gerlach, D. (1977). Botanische Mikrotechnik, G. Thieme, Stuttgart

Gladfelter, W B. (1975). Sea anemone with zooxanthellae: simultaneous contraction and expansion in response to changing light intensity. Science, N. Y. 189: 570-571

Goreau, T. F. (1959). The coral reefs of Jamaica, I. Species composition and zonation. Ecology 40: 67-90

Goreau, T. F. (1963). Calcium carbonate deposition by coralline algae and corals in relation to their role as reef builders. Ann. N. A. Acad. Sci. 109: 127-167

Goreau, T. F., Wells, J. W. (1967). The shallow water scleractinia of Jamaica: revised list of species and their vertical distribution range. Bull. mar. Sci. 17: 442-953

Kanwisher, J. W., Wainwright, S. A. (1967). Oxygen balance of some reef corals. Biol. Bull. mar. biol. Lab., Woods Hole 133: $378-390$

Kawaguti, S. (1937). On the physiology of reef corals. I. On the oxygen exchange of reef corals. Palao. Trop. Biol. Sta. Stud. 1: $187-198$

Lasker, H. R. (1979). Light dependent activity patterns among reef corals: Montastrea cavernosa. Biol. Bull. mar. biol. Lab., Woods Hole 156: 196-211

Loya, Y. (1972). Community structure and species diversity of hermatypic corals at Eilat, Red Sea. Mar. Biol. 13: 100-123

Loya, Y., Slobodkin, L. B. (1971). The coral reefs of Eilat (Golf of Eilat, Red Sea). Symp. zool. Soc. Lond. 28: 117-139

Mergner, H., Svoboda, A. (1977). Productivity and seasonal changes in selected reef areas in the Golf of Aqaba (Red Sea). Helgoländer wiss. Meeresunters. 30: 383-399

Muscatine, L., Porter, J. W. (1977). Reef corals. Mutualistic symbiosis adapted to nutrient-poor environments. BioScience 27: 454-460

Pearse, V. B. (1974). Modifications of sea anemone behaviour by symbiotic zooxanthellae: expansion and contraction. Biol. Bull. mar. biol. Lab. Woods Hole 147: 641-651

Pichon, M. (1972). The coral reefs of Madagaskar. In Battis- 
tini, R., Richard-Vindard, G., (eds.) Biogeography and ecology in Madagaskar. Dr. W. Junk B. V. Pbl., The Hague, pp. $367-410$

Porter, J. W (1976). Autotrophy, heterotrophy, and resource partitioning in Caribean reef corals. Am. Nat. 110: $731-742$

Scheer, R. G. (1971). Coral reefs and coral genera in the Red Sea and Indian Ocean. Symp. zool. Soc. Lond. 28: 329-367

Sebens, K. P., DeRiemer, K. (1977). Diel cycles of expansion and contraction in coral reef anthozoans. Mar. Biol. 43: 247-256

Veron, J. E. N., Pichon, M. (1980). Scleractinia of Eastern
Australia, Part III. Austr. Inst. Mar. Sci. Monograph Ser., Vol. 4

Vollenweiler, R. A. (ed.) (1969). A manual on methods for measuring primary production in aquatic environments. IBP Handbook No. 12, Blackwell Scientific Publications, Oxford

Wells, J. W. (1954). Recent corals of the Marshall Islands, Bikini and nearby atolls. Part 2, Oceanography (Biol.). Prof. Pap. U. S. geol. Surv. 260 (1): 385-486

Wethey, D. S., Porter, J. W. (1976). Sun and shade differences in productivity of reef corals. Nature, Lond. 262: 281-282

This paper was presented by Dr. Y. Loya; it was accepted for printing on November 6, 1981 